\title{
Motherhood and biosafety measures: Negotiating a compromise between traditional funeral customs and public health needs in Zimbabwe in the wake of COVID-19
}

\begin{tabular}{|c|c|}
\hline $\begin{array}{l}\text { Author: } \\
\text { Canisius Mwa }\end{array}$ & ndayi ${ }^{1,2}$ (1) \\
\hline $\begin{array}{l}\text { Affiliations: } \\
{ }^{1} \text { Department } \\
\text { Religious Stud } \\
\text { of Arts, Midla } \\
\text { University, Gu }\end{array}$ & $\begin{array}{l}\text { ff } \\
\text { ies, Faculty } \\
\text { dds State } \\
\text { eru, Zimbabwe }\end{array}$ \\
\hline $\begin{array}{l}{ }^{2} \text { Research Inst } \\
\text { Theology and } \\
\text { Faculty of Arts } \\
\text { South Africa, } \\
\text { South Africa }\end{array}$ & $\begin{array}{l}\text { itute for } \\
\text { Religion, } \\
\text {, University of } \\
\text { retoria, }\end{array}$ \\
\hline $\begin{array}{l}\text { Correspondin } \\
\text { Canisius Mwa } \\
\text { canisiusm@gr }\end{array}$ & $\begin{array}{l}\text { g author: } \\
\text { ndayi, } \\
\text { nail.com }\end{array}$ \\
\hline $\begin{array}{l}\text { Dates: } \\
\text { Received: } 07 \\
\text { Accepted: } 06 \\
\text { Published: } 07\end{array}$ & $\begin{array}{l}\text { pr. } 2021 \\
\text { uly } 2021 \\
\text { Sept. } 2021\end{array}$ \\
\hline $\begin{array}{l}\text { How to cite th } \\
\text { Mwandayi, C., } \\
\text { 'Motherhood } \\
\text { measures: Ne } \\
\text { compromise b } \\
\text { traditional fur } \\
\text { and public he } \\
\text { Zimbabwe in } \\
\text { COVID-19', HT } \\
\text { Studies/Theol } \\
77(2) \text {, a6712. } \\
\text { org/10.4102/ }\end{array}$ & $\begin{array}{l}\text { is article: } \\
2021 \text {, } \\
\text { and biosafety } \\
\text { gotiating a } \\
\text { etween } \\
\text { eral customs } \\
\text { lth needs in } \\
\text { he wake of } \\
\text { S Teologiese } \\
\text { gical Studies } \\
\text { https://doi. } \\
\text { tts.v77i2.6712 }\end{array}$ \\
\hline $\begin{array}{l}\text { Copyright: } \\
\text { C 2021. The } \\
\text { Licensee: AOS } \\
\text { is licensed un } \\
\text { Creative Comı } \\
\text { Attribution Lic }\end{array}$ & $\begin{array}{l}\text { uthors. } \\
\text { S. This work } \\
\text { ler the } \\
\text { nons } \\
\text { ense. }\end{array}$ \\
\hline Read online: & \\
\hline 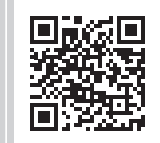 & $\begin{array}{l}\text { Scan this QR } \\
\text { code with your } \\
\text { smart phone or } \\
\text { mobile device } \\
\text { to read online. }\end{array}$ \\
\hline
\end{tabular}

Since the origins of humanity, motherhood has remained a central cog around which human societies revolve. With motherhood, it is not just the ability to give birth but the unbounded love, tolerance, patience and presence associated with a mother that keep motherhood unique. The onset of the ravaging coronavirus 2019 (COVID-19) pandemic and its variants have, however, seen a painful shift from some of these widely held expectations about motherhood. In Zimbabwe, the God-ordained Edenic bond is now under threat as mothers are now barred not only from griefly cuddling the deceased fruit of their womb but also from performing the last mourning rites on them. In line with biosafety measures, they are now to keep distance from them when they are laid to rest. Faced with such competing values, the paper advocates a compromise by arguing for safe and dignified burials as well as Mariopraxis in the midst of a seemingly defenceless situation. Employing synchronic methodologies namely close-reading and feminism, the paper interrogates the God-ordained Edenic bond which provides the basis to what motherhood is all about. The paper deliberately picks on Shona women on the grounds of acquaintance. Having been born to a Shona mother and raised within a Shona cultural environment, much of my ideas about Shona women will be drawn from interaction with my mother as well as with other Shona women. Desk research will be used to augment prior knowledge.

Contribution: The research makes a unique contribution to women theology and the epidemics through proffering tangible ways to both the government and Shona mothers in dealing with emerging challenges associated with the COVID-19 pandemic. Given that women theology is a theology of hope, the article advocates Mariopraxis as it accords mothers the ability, through God, to face the pandemic with an assured hope that God is in control of everything.

Keywords: COVID-19; edenic bond; motherhood; Shona; biosafety.

\section{Introduction}

An anonymous author once remarked about death as:

Love is stronger than death even though it can't stop death from happening, but no matter how hard death tries it can't separate people from love. It can't take away our memories either. In the end, life is stronger than death. (cited in Jenson 2015:68)

The above quote summarises what this article is all about. It grapples with how the COVID-19 pandemic is threatening to break apart the God-ordained Edenic bond ${ }^{1}$ between mothers and their offspring, but mothers should not give up for life is stronger than death. Since the onset of the pandemic, human life has increasingly been put in danger. The pandemic as noted by (IASC 2020) 'has changed the lives of individuals, communities and societies across the world'. Many a time, mothers in particular, find themselves faced with a difficult choice between two competing and conflicting values, cultural versus public healthcare values. The first section of this article interrogates the institution of motherhood in light of the Edenic framework. The second section

1.Taken as a whole, the biblical story of Eden provides the foundation upon which the rest of the interpretation in the Old Testament hinges. As argued by Sawyer (2002:29), in the opening chapters of Genesis (Chapters 1-3), the triangular relationship of God, man and woman is set in place to explain and inform subsequent narrative and legislation as it unfolds. The term 'Edenic bond' is basically used here to refer to a strong, unbreakable attachment between a mother and her offspring which comes against the backdrop of a punishment for disobedience. It is awesome to note that from what was meant to be negative (the pain of childbearing), a strong bond between a mother and a child was ushered.

Note: Special Collection: Women Theologies, sub-edited by Sinenhlanhla S. Chisale (Midlands State University) and Tanya van Wyk (University of Pretoria). 
discusses the motherly bond characteristic of Shona women and how this is now under threat because of COVID-19 and its variants. Lastly, the article advocates contextualised 'safe and dignified' burials as well as proffering Mariopraxis ${ }^{2}$ a pragmatic theological solution to the new reality.

\section{Theoretical framework}

The Edenic bond framework is the overarching theory guiding the discussion in this article. Theologically, human relations had their origins in the Garden of Eden; for that is where human life started. It is from the story of Eden that one derives what can be regarded as the Edenic bond which is basically a strong, unbreakable attachment between a mother and her offspring. While the Lord is said to have cursed the woman with the words: 'I will intensify the pangs of your childbearing; in pain shall you bring forth children' (Gn 3:16), something positive came out of the curse namely: a strong bond between a mother and the child. A curse, so elucidates Pedersen, means 'everything which is bad and harmful, everything which does not agree with the normal relationships, the negation of life' (Pedersen cited in Skulkina 2013:11). What transpires here affirms a centuries old aphorism that God writes straight with crooked lines. From what appears negative to human eyes, God is able to create something good.

A closer look at the curse itself shows at least two dimensions in which the woman would suffer. The first part of the curse: 'I will intensify the pangs of your childbearing' relates to the physical process of giving birth to a child which of course is preceded by the period of pregnancy. Although the pregnancy period is not mentioned by name, the pain associated with it is almost common for every woman, let alone some who develop real complications. As one biblical commentator, Gill (2021) pointed out:

$[T]$ he many and great sorrows endured by women from the time of conception to giving birth range from nausea, a loathing of food, dizziness, pains in the head and teeth, faintings and swoonings, danger of miscarriage, to even the trouble of bearing such a burden, especially when it grows heavy. (n.p.)

Some complications can even be fatal or lead to early deliveries. The same applies with the actual process of giving birth. Even though some women are quick to forget labour pains just after delivery, as alluded to also by Jesus in John 16:21, reliving the memories of this act are tales of intense pain. In intensifying the pain of childbearing, God possibly had a purpose for the woman, never ever was she to forget that which had caused her pain.

The second dimension in which a woman would suffer is couched in the second part of the curse: 'in pain shall you bring forth children'. 'Bringing forth' here needs to be understood not just as giving birth but also in the context of raising the child. This finds support in the words of Stedman (2021) who, looking at the whole context in which the curse has been developed, came to a conclusion that the pain being alluded to here mean more than simply physical pain of delivering a child, but it refers also to the heartbreak associated with having children'. For him, 'this is the woman's primary experience as a result of the fall, the presence of heartbreak in rearing children'. A threat to a child is pain to a mother's heart.

While child minding is one of the interesting, funny, and lovely experiences, it is indeed often intertwined with agonies also. The pain of bringing forth a child ranges from sleepless nights, seeing a child suffereing from an illness to even loss of the child in certain circumstances. It is such experiences that a make the bond between a mother and her child so strong and ineradicable. Naturally, minding an infant $24 / 7$ creates an inerasable bond which even death cannot manage to tear apart. Once a mother brings up a child with love then the bond is for eternity. Given this bond, a mother becomes so involved in the life of her children that what they feel, she feels; if they fail, she feels the heartbreak of it particularly strongly. As summed up by Stedman (2021):

$[A]$ mother's heart is wrapped up with the life and career of her children. She lives in and by her children. The meaning of her life is revealed in them, and if they succeed, she has succeeded, but if they fail, she has failed. (n.p.)

When compared to the first dimension of pain which a woman suffers, it would appear it is the second dimension which creates a more lasting and enduring bond.

The Edenic bond framework thus provides a paradigm for analysing the Biblical narratives of the bond between women with their offsprings; and the story of Rizpah and her sons stands out to be one of the most shining example. The story of Rizpah is used in this article not so much to engage with Shona cultural practices but to illustrate the love of a mother. The Edenic bond is also a framework for rationalising the love and pain of bringing up a child experienced by Shona women but at the end losing them painfully to COVID-19. The same framework provides a rational basis for mobilising mothers in contemporary times to place everything in the hands of God on the understanding that it was him from the beginning who granted humanity a share in his creative work through procreation.

A follow up on the evolvement of motherhood after the Edenic event is important. It is critical in two ways: in the first place it helps to illustrate points of synergies between motherhood as originally designed by God and what we continue to see today; secondly, it grounds the call for a compromise between traditional funeral rites and biosafety measures on the essence of the God-ordained Edenic bond that has stood the test of time.

\section{The institution of motherhood}

Since time immemorial, motherhood has remained a key structure in human life. This resonates with the observation by the Global Volunteers organisation (2002), that throughout 
history, 'the central role of women in society has ensured the stability, progress and long-term development of nations'. Although the notion of motherhood is expressed differently over time and varies across social class, race, ethnicity and culture, in most societies and particularly in Africa, as noted by Ghosh (2016:19), 'motherhood ideally begins with heterosexual relations through social/legal marriage between a man and woman'.

It is important to note, however, that while motherhood ideally begins with heterosexual relations through marriage between a man and a woman, there are different types of mothers the world over. There are some who are mothers not as a result of a marriage but through mere cohabitation with a male partner whilst others become so through sexual unions with any man they find. While some mothers have a heart for their children it is equally important to mention that some mothers do not take care of their children, in other words they do not display any affection for them. Also, not all women become mothers; some, because of different reasons, may remain single the rest of their lives without any biological offspring of theirs. Of importance to mention also is the distinction between mothering and motherhood. Mothering, as argued by Ghosh (2016:18), normally relates to taking care of the physical and emotional needs of dependent children. One does not need to be the real mother to perform such activities; any woman, a gay or lesbian guardian may equally perform them.

On the other hand, 'motherhood is a larger social institution and is characterized by specific meanings and ideologies' (Ghosh 2016:19). The institution involves the potential role of a women as wife, as mother, as daughter-in-law, and so on. The ideology of motherhood is stereotyped in almost all the societies and a girl is generally expected, since birth, to take such role after marriage. Motherhood, as further argued by Ghosh (2016:19-20) is therefore a patriarchal construction given that the socialised roles of women attached to motherhood as potential mothers, wives or daughter in-laws are considered inferior and subordinate to male roles as bread winners. As the traditional role of women are not considered 'productive', patriarchy makes women dependent on men for livelihood and security, and this further reinforces their subordination in family and society. It is not however in the immediate interest of this article to follow up on the different types of mothers, save to say that the positive paradigm with regard to motherhood which this article is interested in is not true for all societies. The positive paradigm with regard to motherhood, however, remains critical in this article because the other dimensions of motherhood from a biblical angle appear human distortions of God's original design of motherhood.

\section{Biblical motherhood: The case of Rizpah and her sons}

Given that the biblical story of Eden provides a profound portrayal of God's original design for human relationships and is set forth as a pattern for all future relationships, one is able to see that subsequent biblical narratives of women's relationship with their offspring reflect a continuity of the Edenic bond model. The story of Rizpah and her sons (2 Sm 21:6f.), stands out to be one of the most shining example that is worth noting. Assuming that readers know the story already, it is a masterpiece which demonstrates to what lengths a mother's bond of love, patience and forbearance for her offspring can go.

The author appears little interested in the gaps in the story as he is in the way in which David tried to clean up Saul's mess as well as portraying David as a concerned king who ordered proper burials of the slain men including that of Saul and Jonathan after seeing what Rizpah had done. Seeing, however, a counter-narrative to what the court historian of David portrayed, Joo (2019) for example, avers that:

Rizpah does not just mourn the death of her sons and nephews but protests the unjust actions of King David. By boldly sitting on a boulder, Rizpah challenged the Davidic court's attempt to promulgate its master narrative. (n.p.)

In so doing, she exposed David's involvement in the murder of the Saulide family. Consequently, she subverts the master narrative in which the court historian tries to present David as the faithful restorer of fertility in the land. A detailed follow up on this counter-narrative, however, lies beyond the purview of this current work but what Rizpah did is enough to articulate in clear terms the unshakable love of a mother. In Israelite culture, it was a great dishonor to leave a corpse to be eaten by animals and birds and so Rizpah being a devoted mother, refused to allow her sons to suffer this final indignity (Weanzana 2006:406). While the Rizpha story could have been told from the vantage point of David, the story indirectly brings out the uniqueness of motherhood; that mothers, no matter what challenges, are able to stand with their own, beyond even physical death. Such is the case we see among Shona women, in particular when it comes to the issue of death.

\section{Motherhood among the Shona}

From orally passed information as well as from documented sources, it can generally be noted that in the pre-Christian religious heritage of the Shona peoples of Zimbabwe, women were considered unimportant (Mukonyora 1999). Given that men viewed themselves as the official custodians of the land, something which was evident from rituals held in honour of the patrilineal ancestors, women remained subordinate to men. Even though some could become spirit mediums and diviners, women largely remained confined to household chores and the garden. In such setups where they were viewed as vatorwa, 'the ones from outside the lineage in a system of exogamy', what was expected of a woman was largely a creation of the males as they viewed themselves as the people who mattered most before the ancestors. What it meant therefore to be mother in the home, before the husband, before children as well as before society was determined by what men in a particular cultural set up saw as acceptable and right before the ancestors. Ghosh (2016) was thus not wrong when he viewed the stereotype of 
motherhood as a patriarchal construction. Although his observation was largely drawn from an Indian patriarchal society, his remark applies so well in any patriarchal society including the Shona society of the time.

The dawn of independence in Zimbabwe (1980) began to witness notable changes being made to address the plight of women. The important role which they had played during the war of liberation helped to change their status in the society (Bourdillon 1976:56). Such an official recognition saw the launch of the Ministry of Women's Affairs, Gender and Community Development in 1980, as well as the passing of the Legal Age of Majority Act in 1982 (Bourdillon 1976:56). The Bill officially gave all people of Zimbabwe, including women, full adult status on reaching the age of 18 . What this implied was that women were recognised as being at par with men and hence they could enjoy the same freedom as men, even enter into any employment sector without much hindrance. Education was made open to all and some women began to openly challenge several facets of tradition which they felt were oppressive to the women folk. Some men too began to see some of the pitfalls of their traditional customs and hence they began to listen with sympathy to women's voices of discontent. What it means to be a mother began to be re-defined, with women taking a leading role in such reconstructions. While, for example, in earlier days a woman only enjoyed respect in her lineage provided she was someone else's wife through marriage (Mukonyora 1999), in today's society single motherhood is now generally being accepted and is no longer being frowned upon.

Although women are now being recognised at par with men, in a number of cases women still stand disadvantaged and end up bearing much of the consequences when drastic policies are made by those in authority. Zimbabwe still being largely a patriarchal society, women aspirations and stories appear less desirable to write about except when they are caught in a scandal. It is against this background that this article intentionally picks up on these often 'forgotten' elements of our society paying particular attention to the endangered motherly bond in the wake of the COVID-19 pandemic.

By focussing on women in the article, is not to say that other elements of the society, for example, the youths, fathers, and young children do not feel the effects of COVID-19. Women, and in particular mothers, have been chosen because they are arguably the worst hit by the pandemic. For example, since the start of lockdown in Zimbabwe (2020), it is reported that the 'pandemic has worsened gender inequalities as women and girls continue to bear the brunt of unpaid labour, while being disproportionately at risk of violence compared to their male counterparts' (Chibamu 2021). According to a report by the Zimbabwe Spotlight Initiative, 'the pandemic has cast a pall on the progress made in achieving gender equality by 2030 in Zimbabwe as part of the 2030 Agenda for Sustainable Development' (Zimbabwe Spotlight Initiative cited in Chibamu 2021). Apart from an increase in domestic violence, teenage pregnancies were also said to be on the rise as a result of lockdowns and from a report by Sithembiso
Nyoni, an estimated figure of around 900 girls below 18 had been raped in the last quarter of 2020 alone (Chibamu 2021).

Compared to their male counterparts, women have an increased risk of being infected by the virus given their predominant roles as caregivers within families and communities. Affirming the central role played by women and the urgency to achieve gender equality, partners led by United Nations' Country representative Maria Ribeiro with support from the European Union (EU) argued:

[W] hile the COVID-19 pandemic continues and efforts to curb its spread intensify, now is the time to equally buckle up and work hard to achieve gender equality in spite of the challenges the pandemic has revealed. (UN Zimbabwe 2021:n.p.)

Since women are at the forefront of fighting the COVID-19 pandemic as healthcare and frontline workers both at institutional level and at home, it is quite unfortunate that after shouldering all these burdens, they remain the least recognised. Under such circumstances, it is therefore justified to devote some attention to them. As indicated earlier on, it is not everything about motherhood that this article seeks to focus on, but rather on the Edenic bond between mothers and their offsprings that the pandemic is threatening to break apart.

\section{Shona women in death scenarios}

Customarily among the Shona, a dead body should not be left unattended, there has to be someone to watch over the dead person. Linked to the Edenic bond, it is usually women who sit in the hut where the corpse would-be lying-in state and men position themselves outside the hut, but some may regularly come into the hut especially when there is need. Female relatives from the deceased's maternal side take turns to position themselves beside the dead body to provide company, shade, and where need be protect the body from rodents and flies. As they are the ones who saw the deceased person initially enter this world and cared for him or her, they feel it is their responsibility to see this person depart from this world still in their care. Owing to the established maternal bond, their presence permeates throughout a person's life. Motherhood in this sense is taken as a social responsibility. Therefore, all the women from the deceased's maternal side feel they are mothers of the deceased owing to the same blood that they share with the one who physically gave birth to one who has passed away.

As a sign of appreciation for the work they would have done, these women generally known as vanamai vomumvuri (shade mothers) are usually given a blanket which was used by the deceased person as well as part of the fuko (cloth used to cover the corpse) when the burial is over. If the funeral takes place away from the immediate reach of the relatives from the mother's side, any female person sharing the same totem with the deceased person's mother stands in as the mother.

Though Shona traditional culture evolved outside the biblical culture, it indirectly safeguarded the biblical truths around the importance of a mother in one's life as it does 
not take lightly to any deviation from the prescribed norms that involve maternal bonds. In traditional culture, it is actually a punishable offense if a deceased person is buried without the presence of his or her maternal relatives. What is clearly demonstrated here is that it is God's original design for all cultures that motherhood remains a key structure and a central cog around which human families and societies revolve.

Though it is possible to view the roles played by women at funerals as some of those patriarchal constructions, an idea mooted by Ghosh (2016), I think we should not give a blind eye to the God-ordained natural affection that mothers, without necessarily the influence of men, have towards their offsprings. While some authoritative males are indeed responsible for constructing gender roles through labelling 'good-enough mothers' as ones whose lives are tied to the welfare of their offspring and singling out women who are single and preoccupied with themselves as deviant (Lawler 2002; Winnicott 1953), I would still want to think that the Edenic bond is not something which is socialised but rather something which just comes naturally.

While Shona men at funerals have their own significant roles to play, I think it is not overly stretching to say that without women, funeral rites are not just incomplete but unperformable. This speaks volumes about the impact of the Edenic bond in the lives of peoples as well as the power wielded by women in matters of death though many a time men appear to be at the forefront in the funeral arrangements. Kamwendo and Manyeruke (2017) refer to this as the bedroom board meetings, whereby women decide in private, and men appear in public only as spokespersons of the bedroom board meeting deliberations. To radical feminists, however, wifehood and motherhood are an enslavement of women. Rich (1977), for example, argues, 'the oppressive institution of motherhood forces a number of women to sacrifice career lives and become mothers who stay at home doing segregated gender roles'. Be that as it may, it is the argument of this article that motherhood is in fact women's means of empowerment (Mwandayi \& Sipeyiye 2018). In death related matters, there is actually a subversion of the commonly assumed female inferiority as males from the maternal side of a deceased woman, for example, are usually counted on the motherly side. In such scenarios, men lose their identity as males and they assume feminine voices in whatever decisions that need to be made. Motherhood, therefore, has remained among the Shona as a central pinion around which human families and societies revolve.

\section{Shona traditional funerals amidst the spike of COVID-19 and its variant cases}

Since time immemorial, women have secured a unique position in Shona traditional funerals and in matters of death. No one ever thought a time would come when the cherished traditional norms would come under threat, when all that which is expected of a mother would potentially become a danger to humanity. The onset of COVID-19 and its variants turned around the world order and the unexpected became the new normal.

While the first wave of COVID-19 took away many lives especially in the Western world in 2020, it was the second wave coupled with its variant mutations that hit Africa at the beginning of 2021 which led most African governments to tighten up their restriction rules. It was against this background that on 11 January 2021, the government of Zimbabwe announced that it was banning traditional funeral rites as part of the measures to stop the spread of the coronavirus in the country. Speaking to the media, the police spokesperson said:

The Zimbabwe Republic Police advises the public that the Ministry of Health and Child Care has informed the police of immediate restrictions imposed on the movement of dead bodies for burial in the country. According to health officials, a body will now be buried in the town/city where the death would have taken place. This is being done in order to curtail the spread of COVID-19 pandemic. In this regard, police will only clear body movements for burial straight from a funeral parlor/hospital mortuary to the burial site. No body-viewing will be allowed, and bodies will not be taken home. (Nyathi cited in Xinhua 2021:n.p.)

While the announcement was good intentioned, it came as a shock to most people who angrily reacted to it. Becuase of the pressure following the public outcry, the Ministry of Health and Child Care was forced to review its earlier position that a dead body will have to be buried in the town/city where the death had taken place. In its reviewed statement, the Ministry of Health's director of environmental health, Victor Nyamande, said:

For those who want to transport the body for burial outside the city or town of death, they should ensure that the body is hermetically sealed in a triple coffin before collection of body from funeral parlour or hospital mortuary... The public is urged to keep a distance of 4 metres as the body is lowered into the grave by either city health or funeral parlour officials...There will be no body-viewing or taking of bodies home. From the airport or land border, the remains will be taken straight to the gravesite as indicated. (Nyamande cited in Chikwati \& Muleya 2021:n.p.)

Although the new announcement was a clear climb down by the government from its earlier position, it had not eased much according to the expectations of many. There was still an outcry in view of the costs of hermetically sealed coffins. Given that the COVID-19 pandemic hit the country that was already economically stressed, the price of hermetically sealed coffins proved beyond what most civil servants and the bulk of city dwellers could afford (Taruvinga 2021).

Lack of adequate resources saw many having to abide by the government protocol of having their dear ones buried in towns / cities where they had passed on. The directive did not go down well for many as some saw this as a sign of 
insensitivity on the part of the government. The government was blamed for disrespecting culture by making the deceased buried by strangers in the midst of strangers, while a handful of mourning relatives stood at some distance away. Speaking out what is shared by many, one Harare resident is said to have remarked:

It is against our culture to be buried by strangers in the midst of strangers. We want to be buried among our ancestors. It is unheard of that an adult is buried by only a few people. (Kepekepe cited in Taruvinga 2021:n.p.)

Many would long for traditional funerals whereby a deceased person is taken back to his or her ancestral roots to be buried among his or her people, buried by close relatives and not strangers with all the last filial rituals performed. 'Culture', as rightly noted by Kamwendo and Manyeruke (2017), 'has its own syllabus as to how a funeral should be conducted'. Any violation of such cultural expectations is tantamount to an insult.

\section{Locating Shona mothers in the midst of the ban of movement and traditional funerals}

When the first lockdown in Zimbabwe was announced, the law enforcement agents were so intolerant towards what they viewed as violations of the lockdown rules that majority of the Zimbabweans were forced to remain indoors. What these people ate and drank in these homes were almost of no concern to the government as no comprehensive plans were made to bring food hampers to these families compared to what was happening say for example in South Africa and other parts of the developed world. While in 2020, a social support cash transfer grant of ZW\$600 million was announced by the government and about 60,000 vulnerable urban families received cushion allowances in September 2020, there were still complaints over the paltry ZW $\$ 1500$ allowance which could not feed a family of six because of the high cost of basic commodities (Moyo 2021).

The stress of how and what the family would eat fell directly on women especially mothers (Nevill 2020). Mothers were not only worried about food issues, but controlling kids who were out of school and just seated at home was another mammoth task. This find echo in the observation by Tarinda (2021) who notes that with children now at home:

$[W]$ omen and girls are more likely to suffer the primary and secondary impacts of the virus, including increased risk of being infected by the virus, given their predominant roles as caregivers within families and communities. This also includes other care responsibilities which will be frequently "downloaded" onto females, such as looking after the sick and the elderly, home learning facilitation for children and siblings, and increased social and household chores. (n.p.)

It indeed proved to be a torrid time for mothers but their struggles received hardly any attention. Because of moyo wokubereka 'maternal heart', many were forced to leave their homes in search of food to fend for their families, but the unfortunate ones had to endure running battles with the police and soldiers.

When the second lockdown came, women were again the ones to suffer more. While there was some flexibility in terms of movement during the second lockdown, what turned out to be the worst blow for women was the failure to fully perform motherly duties towards family members who had fallen victim to the coronavirus. Though the COVID-19 restrictions were all instituted for the benefit of the surviving members so that they do not contract the virus, instead it turned out to be a huge stone which weighed on the hearts of most mothers. The Edenic bond which had been built up over the years made it difficult for most mothers to accept that surely those that they had held so dear to them over the years, cared for with so much love and grew so fond of each time they were away, had disappeared in a short period of time and worse that they could not be afforded the opportunity to see and say good-bye to them for the last time. COVID related deaths have proved cruel for most mothers, and many are left with shattered hopes, depleted confidence in the country's heathcare systems, devastated by the decision taken by the leaders, as also shaken faith. Given such a scenario, one can only agree with Rosemary Radford Reuther's conviction that 'at the intersection of gender and other social marginalisation, women are representative of the oppressed of the oppressed' (Reuther cited in Chimhanda 2014). Picking up from Reuther, Chimhanda (2014) aptly points out that in the context of Shona culture, the motif of women as representing the 'oppressed of the oppressed' is seen in situations of crises in relation to contesting values. The ban on traditional funerals in the name of biosafety indeed created a clash of values and as argued already, women turned out to be the oppressed of the oppressed. When shall our mothers get liberated and consoled one may wonder? In the midst of shattered hopes and shaken faith, what can help them see the light again at the end of the dark tunnel? In such a seemingly cruel world, there is need to draw up solutions that take into cognisance the God-ordained Edenic bond so as to address the pain that our mothers are experiencing as well as to restore their shattered hopes. It is against this need that I suggest a two-pronged approach to the current reality. Firstly, on the side of the government, there is a need to urgently work towards contextualising biosafety measures and secondly, on the side of women, there is need to embrace Mariopraxis.

\section{Culturally friendly infection containment measures}

As alluded above, the government ban on traditional funerary rites has not been well received by some sections of the Zimbabwean society who feel the government was out to rob people of what was left of value in their culture. Given the high emotive response from the public, there is urgent need that the government respect people's cultural beliefs but at the same time taking cognisance of recommendations of the World Health Organization (WHO), to minimise the spread of the virus. One critical way to respect people's 
cultural beliefs would be not to forget the place of a mother in death scenarios but to take it as sine quo non position designed by God for a purpose. If mothers continue to be taken as by-standers when those they were deeply bonded to are laid to rest, then people may be justified in seeing the government as robbing them of what was left of value in their culture. Even for converted Christians, the position of a mother in one's life or at the point of death is not something one can afford to sacrifice. There are certain cultural elements that cannot be sacrificed on the altar of conversion, hence the call for inculturation in some African theological circles.

While safety should remain the hallmark of every action that people do during this COVID era, people need to be afforded the opportunity to provide dignified burials for their dear ones. If it means training teams within our community not only on how to safely bury someone, but also to carefully look after the COVID infected victims within our communities, then the government should not hesitate in mobilising funds for such a worthy cause. The absence of such need for training among the response priorities covered in the Zimbabwe COVID-19 Addendum (OCHA 2020), is a cause for concern. Community participation in COVID-19 burials should not be taken for granted. The call by the general public for the government to be culture sensitive is an important lesson in that competing cultural and public health values need to be balanced.

To allay public discontent over government restrictions, there is need to allow family members to assume active roles in the burial of COVID victims. While women aligned to the maternal side of the deceased may no longer wash and dress corpses of dear ones as in normal situations, in pursuance of the Edenic bond, they should at least be allowed to perform certain rites which are culture sensitive but safe. They may, for example, be allowed to continue with 'guarding' the body but with practising social distancing as well as wearing masks. To aid safety, regular fumigation of the house where the corpse would be lying-in-state should be prioritised. The government needs to ensure that provision of adequate protective personal equipment (PPEs) is prioritised and women who would be front players at funerals should have access to this equipment. If such an equipment is in place, it means they can even be allowed to continue with the traditional washing of the body. It is important to note that even in the recommendations made by WHO and other bodies, the risk of viral transmission while preparing the body of a person infected with COVID-19 is low. However, there is still the need to support the family members, the traditional and religious leaders, and the healthcare workers who are typically involved in preparing the body for burial with information and PPEs to reduce the risk of transmission. The WHO further encourages that in close communication with communities, agreements be made on burial ceremonies that reduce the risk of infection 'but at the same time meet local cultural, social and religious needs'. Culturally inappropriate burials that have the potential to cause longlasting psychological, social and legal problems for families of the deceased should at all costs be avoided (IASC 2020). Mokuwa and Richards (2020) were thus right to argue that 'shooting down pleas to perform culturally important death and burial practices in the name of biosafety (is) not helpful', and it will surely prove counter-productive.

\section{The theology of Mariopraxis}

The second solution I suggest to the present predicament is that of Mariopraxis. As explained earlier, Mariopraxis is all about engaging, applying or practicing lessons derived from Mary, the mother of Jesus. Tracing back to the Edenic bond, Mary, just like any mother, undoubtedly had developed an unshakable bond with her son not only because he was the only one she had, but also that the mother and son could have stayed together for quite some time given the early disappearance of Joseph from the gospel narratives. Probably, Joseph died early and left the two to themselves. Naturally, in such an environment, family bonds get to become stronger.

Just like in contemporary times when mothers are cruelly losing their sons and daughters to the pandemic, while Mary enjoyed the warmth of her son's presence, a sword, as probably had been prophesied by Simeon (Luke 2:35), pierced her heart when authorities tried and crucified Jesus before her presence. None of the authorities cared to ask about Mary's feelings or emotions. A verdict that he should die was just passed and Mary helplessly stood among the crowd, watching the drama unfold from a distance. I would like to think that to women nothing surpasses the pain of helplessly seeing one's son/daughter being flogged by a stranger for no apparent reason and in worse scenarios seeing that son/daughter being put to death as one watches. This is typically what Mary had to face. Since she is recorded in the scriptures as not having tried to fight back or having gone so emotional about her son's death, the most probable assumption one can draw from her action is that she surrendered everything in prayer to a higher power than her, namely God. Only the 'prayer of surrender' could have lifted her spirit in such circumstances, hence we find her bold to face the agony her soul was undergoing as well as the agony of her son.

The term 'surrender' etymologically comes from the Greek word 'paradidomi' which basically means to yield up, transmit and entrust. Unpacking what yielding up is all about Patrick (2017) writes that God demands a 'total cling' to Him and not to anyone else. He does not want us to yield or surrender our worries to fellow humans, but our surrender should rather be heavenly - it must be upward. This yielding up is followed by a verbal dialogue with God of what one would be committing to Him. After speaking one's worries or cares to God, then one gives over or entrusts those cares to Him. This is summed up well again in the words of Patrick who says:

Entrusting something to someone means you have placed that person in a legal position of guardianship over something that belongs to you. God becomes your trustee. The key to entrusting is leaving the cares with God and allowing Him to remain the trustee. (n.p.) 
The prayer of surrender therefore entails nothing other than leaving everything in the hands of God. The prayer itself has the backing of scripture which says: 'Cast all your anxiety on Him because He cares for you' (Pt 15:7).

Mary thus becomes a teacher or role model to other women. Given her status as the mother of Jesus, God should have intended to communicate something to other mothers. Her action is a full lesson on what mothers should do when confronted with an unexpected loss of those they are deeply bonded to. Without words, she urges surrender of everything to God in prayer. Once Zimbabwean women are able to master this lesson it means they can be able to withstand the devastation caused by COVID-19 and its variants as well as accept the government's infection containment measures. This resonates well with Maura Roan McKeegan's (2020) observation regarding the prayer of surrender when she says:

It is a prayer that is especially timely now, when world events feel out of control, and we are trying to grow in trust and abandonment to God's providence. It's also timely when our own personal suffering is threatening to overwhelm us and steal our peace. (n.p.)

If Zimbabwean women anchor their faith in Christ through the prayer of surrender, neither death nor the illness of their dear ones can shake them. Christ's atoning sacrifice on the cross, as pointed out by Pali (2014) set believers apart for God and the blood of Christ gives them direct access to God.

Mariopraxis accords mothers the ability, through God, to mourn over the death of their deceased sons and daughters with an assured hope that God being in control of everything will reunite them with their deceased ones in the after-life. Mary had that deep trust and faith in God, and in Christian tradition we hear that when she died, she too was taken up to heaven to enjoy the company of her son, Jesus. The same spirit of assured trust is also reflected in the book of Maccabees where we find a Jewish mother who encouraged her sons to offer up their lives than eat pork which was being enforced on them by the Hellenists. Speaking to her youngest son before he was executed, she encouraged and assured him: 'Do not be afraid of this executioner, but be worthy of your brothers and accept death, so that in the time of mercy I may receive you again with them' (2 Macc 7:30).

Although we have vaccines and the Zimbabwean populace is being inoculated, they are not magic bullets which will put to an end to the COVID related deaths in the foreseeable future. As long as COVID is a world pandemic, mothers are bound to have the God-ordained Edenic bonds with their children shaken up. Mariopraxis is thus not just a tool for the present context alone but can always be of value in the future and even in matters that are not just confined to death issues.

\section{Conclusion}

COVID-19 and its variants have not just turned around the world order, but they have also been responsible for leaving a big wound in the hearts of many. Families have been torn apart, friends and relatives robbed away and the world over people have been forced to remain indoors for fear of the uninvited monster. Among the most affected groups that this article has been looking at are women. Women have been discussed in the context of COVID-related deaths and it has been observed that they tend to suffer more when one of their own passes away because of the deeper bond that is established on the onset of one's life. The God-ordained Edenic bond pushes women to extreme levels of forbearance, love and care to the very end towards their offsprings. It is quite unfortunate that COVID-19 and its variants came as it were to rob away the qualities which make motherhood unique. Aware of their motherly qualities, many feel ashamed and angry that they cannot help in any meaningful way when death robs them of a dear one. Whilst they would love to cuddle and perform the last mourning rites on dear ones, restrictive laws put in place to curb the spread of coronavirus closes them off, thus adding pain to the already bleeding wound. Though women in contemporary public are perceived to be weak, this article has successfully managed to argue that without women, funeral rites are not just incomplete but unperformable. Women related customs in traditional funerals cannot therefore be sacrificed on the altar of biosafety measures, otherwise it would prove counterproductive. It is against this context that the article advocated contextualised biosafety measures as well as Mariopraxis. Mary surrendered or placed everything in God's hands through prayer and this is what Zimbabwean mothers are called on to do more so in the face of COVID-19 and its variants.

\section{Acknowledgements Competing interests}

The author declares that they have no financial or personal relationships that may have inappropriately influenced them in writing this article.

\section{Author's contributions}

C.M. is the sole author of this article.

\section{Ethical considerations}

This article followed all ethical standards for research without direct contact with human or animal subjects.

\section{Funding information}

This research received no specific grant from any funding agency in the public, commercial or not-for-profit sectors.

\section{Data availability}

Data sharing is not applicable to this article as no new data were created or analysed in this study. 


\section{Disclaimer}

The views and opinions expressed in this article are those of the author and do not necessarily reflect the official policy or position of any affiliated agency of the author.

\section{References}

Bourdillon, M.F.C., 1976, The Shona peoples: An ethnography of the contemporary Shona, with special reference to their religion, Mambo Press, Gweru.

Chibamu, A., 2021, 'Covid-19 increases inequalities and violence against women and girls', New Zimbabwe, viewed 02 August 2021, https://www.newzimbabwe.com/ covid-19-increases-inequalities-and-violence-against-women-and-girls/.

Chikwati, E. \& Muleya, T., 2021, 'Movement of corpses clarified', The Herald, viewed 19 March 2021, from https://www.herald.co.zw/movement-of-corpses-clarified/.

Chimhanda, F., 2014, 'The liberation potential of the Shona culture and the Gospel: A post-feminist perspective', Studia Historiae Ecclesiasticae 40(Suppl 1) 305-328.

Ghosh, B., 2016, 'The institution of motherhood: A critical understanding', in S. Manna \& S. Patra (eds.), Motherhood - Demystification and Denouement, pp. 17-29, Levant Books, Kolkata.

Gill, J., 2021, John Gill's exposition of the bible/Genesis 3:16, viewed 07 March 2021, from https://www.biblestudytools.com/commentaries/gills-exposition-of-the-bible/ genesis-3-16.html.

Global Volunteers, 2002, The global role of women - caretakers, conscience, farmers, educators and entrepreneurs, viewed n.d., from https://globalvolunteers.org/globalrole-of-women/

IASC, 2020, Interim guidance: Public health and social measures for COVID-19 preparedness and response operations in low capacity and humanitarian settings, preparedness and response operations in low capacity and humanitarian settings,
Inter-Agency Standing Committee, viewed 07 March 2021, from https://www. Inter-Agency Standing Committee, viewed 07 March 2021, from https://www. preparedness-and-response-in-low-capacity-and-humanitarian-settings.

Jenson, III. L., 2015, '100 heart-wrenching \& powerful quotes about losing a loved one', Thought Catalog, viewed 03 March 2021, from https://thoughtcatalog.com/ one, Thought Catalog, viewed 03 March 2021, from https://thoughtcatalog.com/ a-loved-one $/ 3 /$.

Joo, S., 2019, 'Counter-narratives: Rizpah and the "comfort women" statue', Journal for the study of the Old Testament 44(1), 79-98. https://doi.org/10.1177/ 0309089218772572

Kamwendo, L. \& Manyeruke, C., 2017, 'Power politics during and after funerals amidst the Shona of Zimbabwe', Africology: The Journal of Pan African Studies 10(2), 151-164.

Lawler, S., 2002, Mothering the self: Mothers, daughters, subjects, Routledge, London.
McKeegan, M., 2020, 'The surrender Novena: Let Jesus take care of everything' Catholic Exchange, viewed n.d., from https://catholicexchange.com/thesurrender-novena-let-jesus-take-care-of-everything.

Mokuwa, E. \& Richards, P., 2020, 'How should public health officials respond when important local rituals increase risk of contagion?', Ama Journal of Ethics, viewed n.d., from https://journalofethics.ama-assn.org/article/how-should-public-healthofficials-respond-when-important-local-rituals-increase-risk-contagion/2020-01.

Moyo, P., 2021, 'Mnangagwa's govt cuts off Covid-19 allowances', Bulawayo24 News, viewed n.d., from https://bulawayo24.com/index-id-news-sc-local-byo-201240.html.

Mukonyora, I., 1999, 'Women and ecology in Shona religion', Word and World, xix(3), 276-284.

Mwandayi, C. \& Sipeyiye, M., 2018, LASU Journal of religions and peace studies, Department of Religions and Peace Studies, Lagos State University, Lagos.

Nevill, C., 2020, Zimbabwe: 'Coronavirus will affect women and girls more than anyone', viewed n.d., from https://www.wfp.org/stories/zimbabwe-coronaviruswill-affect-women-and-girls-more-anyone.

OCHA, 2020, Zimbabwe revised humanitarian response plan, viewed n.d., from https://reliefweb.int/report/zimbabwe/zimbabwe-humanitarian-response-plan2020-revised-july-2020-update-covid-19-response.

Pali, K.J., 2014, 'Christ as once for all sacrifice: A cultural reading of Hebrews', Acta Theologica 34(1), 145-172. https://doi.org/10.4314/actat.v34i1.9

Patrick, M., 2017, 'What does it mean to surrender all to God?', Classroom, viewed n.d., from https://classroom.synonym.com/how-to-fast-for-god-12078174.html.

Rich, A., 1977, Of women born: Motherhood as experience and institution, Virago, London.

Skulkina, I., 2013, Blessing and curse in the Old Testament: Socio-cultural aspects, viewed n.d., from https://www.academia.edu/4552166/Blessing and Curse in the_Old_Testament.

Stedman, R., 2021, Love's disciplines, viewed n.d., from https://www.raystedman.org/ old-testament/genesis/loves-disciplines.

Tarinda, S., 2021, Impacts of COVID-19 on women and MSMEs in Zimbabwe, viewed n.d., from https://www.afi-global.org/newsroom/blogs/impacts-of-covid-19-onwomen-and-msmes-in-zimbabwe/.

Taruvinga, M., 2021, “"Buried by strangers": Funeral curbs raise ire in Zimbabwe', Yahoo News, viewed n.d., from https://sg.news.yahoo.com/buried-strangersfuneral-curbs-raise-143600024.html.

United Nations: Zimbabwe, 2021, International women's day: Achieving an equal future in a COVID-19 world, viewed n.d., from https://zimbabwe.un.org/ en/115232-international-womens-day-achieving-equal-future-covid-19-world.

Weanzana, N., 2006, '2 Samuel', in T. Adeyemo, S., Andria, I. Coulibaly, T. Habtu \& S. Ngewa (eds.), Africa Bible commentary, WordAlive Publishers, Nairobi.

Winnicott, D., 1953, 'Transitional objects and transitional phenomena', International Journal of Psychoanalysis 34(2), 89-97.

Xinhua, 2021, 'Zimbabwe orders localized burials to curb Covid-19 spread', Xinhuanet, viewed n.d., from http://www.xinhuanet.com/english/2021-01/11/c_139658958. htm. 